\title{
LOW-TECH INNOVATION AND LOCAL ECONOMIC DEVELOPMENT: CASE STUDY THE TRADITIONAL BATIK INDUSTRY IN PEKALONGAN MUNICIPALITY
}

\author{
Nimas Maninggar ${ }^{1,2}$, Delik Hudalah ${ }^{3}$ \\ Received: 27 September 2017 \\ Accepted: 28 Februari 2018
}

\begin{abstract}
Innovation is no longer purely a project of high-tech industries. The decade has seen a paradigm shift of the meaning and the process of innovation creation from a linear model that largely focuses on $\mathrm{R} \& \mathrm{D}$, toward a non-linear model through informal and interactive processes. As a result, low-tech industries with a low level of R\&D can also make innovations and benefit the regional economy. In Indonesia, such innovation may be linked to the development and survival of cultural industrial clusters. One of Indonesia's unique cultural industries is batik. Using a qualitative analysis, this paper explores the impact of process and product innovations in the batik industry on the local economic development of Pekalongan Municipality, Indonesia's largest batik-producing city. The study is based on semi-structured interviews with batik entrepreneurs, which show that innovations have contributed to the cutting of production costs and, thus, increasing the industrial units' income; the emergence of new batik entrepreneurs; and an increase in tourist visits, supporting businesses and facilities.
\end{abstract}

Keywords: Batik, Innovation, Local Economic Development, Pekalongan

\section{INTRODUCTION}

Innovation and learning have become crucial factors in the regional studies in the era of the knowledge-based economy. The economic paradigm shift from neo-classical theory towards a knowledge-based economy has made economists, policymakers and planners to increasingly focus on stimulating regional competitiveness, which in the end will affect the economic development of the society (Lundvall, Johnson, Andersen, \& Dalum, 2002; Nelson, 2008). Various pieces of empirical evidence have confirmed innovation as one of the drivers of economic development. In the United States, for instance, the implementation of innovation policies in ICT and biopharmaceuticals contributes to an increased multiplier effect, which is three times higher than in any other manufacturing sector (National Research Council \& others, 2013). Meanwhile, high-tech innovation cluster development in Grenoble, France; and Oxfordshire, UK has generated an increase in job opportunities in other sectors such as education, health, services, and construction (Lawton-Smith, 2009; Potter, 2009).

However, innovation as the primary subject of development is still a fuzzy concept due to the obscurity of its concept, theory, standard of empirical evidence and connection with policy (Pike, Rodríguez-Pose, \& Tomaney, 2006). First, the role of the central

\footnotetext{
${ }^{1}$ School of Architecture, Planning and Policy Development, Institut Teknologi Bandung,

2 The Agency for the Assessment and Application of Technology (BPPT)

${ }^{3}$ Research Center for Infrastructure and Regional Studies, Institut Teknologi Bandung
}

Korespondensi: nimas.maninggar@gmail.com 
government has not always been substantial in the empirical explanations. The success of regions has always been explained as the result of innovation and has neglected other conventional factors such as price, costs, and the market. Innovation may be a supporting factor but it is not necessarily the primary driver of the success of a region. Furthermore, innovation has not always lead to economic development (Edquist, Hommen, \& McKelvey, 2001). The discovery of new production technology in an innovation process has a high potency of increasing unemployment. A new product developed by a new company, which eliminates an older product from another company, will also increase unemployment (Blechinger, Kleinknecht, Licht, \& Pfeiffer, 1998).

Another debate concerns the domination of the high-tech sector in the innovation policy literature. Scholars tend to view innovation sectors as identical to the high-tech industry. This viewpoint is the result of the definition of innovation, which has been considered the product of a radical change resulting from a long, expensive and sophisticated research, usually conducted by universities (Abernathy \& Utterback, 1978; Quintas, Wield, \& Massey, 1992). In other words, R\&D is the main factor in creating innovations. It is no surprise that the innovation policy implemented in several developed countries such as the United States, United Kingdom, and France tends towards high-tech industries, exemplified by the development of high-tech regions (Castells \& Hall, 1994).

Innovation creation that is dominated by high-tech industries will discourage the developing countries, which are still dominated by middle and even low-tech industries for innovations. The fundamental characteristic of innovation includes the new combination of ideas, abilities, skills, and existing resources. This basic definition suggests that innovation cannot grow from isolation (Fagerberg, 2003). The interactive process of creating innovation implies the necessity of the inter-connectedness among actors. A number of scholars believe that small-scale industries with low-level R\&D (low-tech industry) are capable of making positive contributions to the economic development of a region (Asheim, Isaksen, Nauwelaers, \& Tödtling, 2003; Hirsch-Kreinsen, Jacobson, Laestadius, \& Smith, 2005).

In 2014, Medium and Small-medium Enterprises have contributed $60.34 \%$ of Indonesia's GDP (Gross Domestic Product) (Kementerian Perindustrian RI, 2016). Indonesia's Medium and Small-medium Enterprises are characterized by low-tech industries with low R\&D levels (Lembaga Pengembangan Perbankan Indonesia \& Bank Indonesia, 2015). One of the industries whose product has been internationally acknowledged as one of Indonesia's original products is Batik. Batik as a traditional culture industry has a high potential for contributing to the regional economy (Fahmi, Koster, \& van Dijk, 2016). The batik industry is classified as a craft sub-sector of the creative economy sector of Indonesia's economy. In 2012, the batik industry contributed $39.71 \%$ of the craft subsector's total export value (Kementerian Perindustrian Republik Indonesia, 2013; Muharti, 2012).

Pekalongan is the largest batik producing region in Indonesia (Nurainun, Hariyana, \& Rasyimah, 2008). The batik industry has become the main economic pillar for Pekalongan's inhabitants, contributing nearly $55.8 \%$ of the total small industrial workforce in the region (Department of Industry, Trade, and small-medium enterprises, 2015). Product innovation is one of the factors in the development and survival of Pekalongan's batik industry (Bakhtiar, Sriyanto, \& Amalia, 2009; Christiana, Pradhanawati, \& Hidayat, 2014).

The objective of this paper is to explain the effect of low-tech industry innovation on local economic development in Pekalongan. The analysis shows that the batik industry has created four types of innovations, including product, process, organization and marketing innovations. They are created through the collaboration of five important actors, i.e., the industry, the government, universities, social organizations, and financial institutions. These innovations provide a positive impact on the local economy through increased 
income, the emergence of new entrepreneurs, and multiplier effects in the service and tourism sectors.

This paper has the following structure. Sections 2 and 3 consist of a literature review on innovation and economic development; and innovation and low-tech industry. Section 4 will discuss the methodology used in this paper. The subsequent section 5 will provide an overview of the case study of the batik industry in Pekalongan. The main analysis (finding and discussion) on the relationship of innovation and the batik industry and the impact of batik innovation on economic development will be discussed in section 6 and 7 . The last section will provide the conclusion.

\section{Innovation and Economic Development}

The innovation theory of Schumpeter states that innovation is important as one of the stimuli of economic development (Schumpeter, 1983). Innovation is the commercialization of an industry's new creations, whether it is a new product, process, market or organization. In its process, Schumpeter introduces "creative destruction", which is creating something new by replacing an old version of the product. The process entails revolutionizing the industry from within, replacing old combinations with new ones in a simultaneous and continuous process (Schumpeter, 1983). Doing so will result in new product combinations that will have an impact on the regional competitiveness.

Innovation contributes to economic development through the emergence of entrepreneurs. Entrepreneurs create new businesses and new businesses provide jobs (Acs, 2006). Few sectors such as ICT, the biopharmaceutical industry and high-tech manufacturing in the United States, France, and the United Kingdom have proven their capability to generate job opportunities in their sector as well as in other sectors (LawtonSmith, 2009; National Research Council \& others, 2013; Potter, 2009). However, the relationship between innovation and entrepreneurs overlaps (Zhao, 2005). On one side, innovation has been considered the trigger for the emergence of new entrepreneurs, yet, on the other side; entrepreneurs are also considered the ones contributing to innovation. In other words, the entrepreneur is an innovation creator. Entrepreneurs create innovation by bringing and implementing new ideas into their production processes (Crumpton, 2012; Rutten, 2005). The new production process will create a new product that will subsequently increase the company's competitiveness. An increased demand for the new product will also trigger a workforce demand that will give a positive impact on the region. The importance of entrepreneurs in economic development led Audretsch \& Keilbach to use entrepreneurs as one of the factors for assessing regional economic performance besides knowledge and capital (Audretsch \& Keilbach, 2004).

There are two success indicators for assessing economic development, i.e., quantitative and qualitative economy appraisal (Rocha, 2004). A qualitative assessment is conducted by measuring the level of work satisfaction. Meanwhile, a quantitative economic assessment, for instance, can be measured by an increase in the number of businesses and income. The establishment of new businesses by entrepreneurs will absorb the workforce, which will, in turn, decrease the unemployment rate (Acs, 2006). The decrease in unemployment will lead to an increase in income that, in turn, will have an effect on people's level of prosperity. Furthermore, the increase in people's prosperity level will also increase the monetary circulation in those regions. Not only that, a successful business development will trigger and influence the growth of other business sectors. This multiplier effect will also have a positive impact on the local government's revenue.

The innovation creation can be divided into two types of innovation, i.e., process and product innovation. Depending on the nature of the innovation, product innovation does not always mean creating more jobs. The product innovation that could give a 
positive impact on creating jobs opportunities is product innovation that doesn't eliminate other product, yet at the same time, it will trigger growth in another sector (Blechinger et al., 1998). Process innovation will affect the improvisation on material usage or work organization, which will also affect production costs. Production costs savings were mentioned as an immediate impact of material improvisation. Thus, the entrepreneur will be able to produce and sell more products, which in the end will raise market demand. Increased market demand means that production will also rise, which will trigger the recruitment of more workers.

This paper will describe the contribution and connection between innovation and entrepreneurs. The relationship occurs because both innovation and entrepreneurs are influencing each other in an industrial development process, which will eventually affect region's economic development. Innovation will create entrepreneur and vice versa.

\section{Innovation and Low-Tech Industry}

Research and Development (R\&D) expenditure is one of the main elements in assessing innovation in the industrial sectors (Hong, Oxley, \& McCann, 2012). The higher the funding for R\&D investment is, the bigger the resulting innovation will be. It is no surprise that innovation is seen as identical with the high-tech industry because it is ranked highest for R\&D expenditure in OECD's industrial sector classification, with an investment of more than $5 \%$ of its expenses (Hatzichronoglou, 1997).

Many studies have been conducted in developed countries on the high-tech industry as the industry with the highest potential in developing innovation. Many countries even built high-tech region to support innovation creation through R\&D, such as the US's Silicon Valley, China's Zhongguancun (ZGC), Japan's Technopolis project, and Taiwan's Hsinchu Area (Castells \& Hall, 1994; Tan, 2006). The over-exploration in the high-tech industry marginalized the low-tech industry in regional economic policies. Discussions on the role of the low-tech industry in increasing the economy through innovations boomed around the 2000s. The emergence of such discussion was preceded by a critique from Hirsch-Kreinsen, $(2008 ; 2005)$ on the consideration of the high-tech industry as the only sector capable of responding to the future innovation and technology challenges. The low-tech industry has been neglected in innovation policy because of the persisting assumption that R\&D is the only main input in creating innovation.

If we look at Schumpeter's original meaning of innovation as discussed above, innovation is something new, whether it is a product or a process, that, according to Rutten, has a social process in its creation (Rutten, 2005). This process refers to the collaboration of numerous actors which implies that innovation itself requires open conditions (Fagerberg, 2003). Innovation requires synergy and interaction of different functions in a company; between suppliers and customers on an inter-firm level, and on a larger scale between a company and other institutions such as research institutions and infrastructure, political and financial firms (Fagerberg, 2003; Park, 2001). The process of interaction in creating innovation implies that the nature of the system is interlinked, interconnected and interrelated between actors. The skill to manage the network between actors with the learning process is, thus, called an innovation system (Cooke \& Memedovic, 2006; Pike et al., 2006).

Thus, R\&D is not the only factor in innovation. The existence of the system, collaboration, and cooperation between actors can become another factor. According to Godin (2008), around half of the innovative companies developed their innovation without R\&D. The low-tech industry, which is dominated by medium and small-medium businesses, has become the driver of innovation development without R\&D (Asheim \& Isaksen, 2003; Godin, 2008). The high-tech industry only acknowledges radical innovation 
as the final result of innovation. When compared to the original meaning of innovation by Schumpeter, then what was meant as innovation is not only something completely new but it can also come from a combination of existing products or processes (Fagerberg, 2003; Rutten, 2005). Thus, a minor change in a product or process can also be called innovation. Furthermore, even designing or changing the design of a product could become the main material in low-tech industry's innovation (Godin, 2008; Kaufmann \& Tödtling, 2003; Mutlu \& Er, 2003).

Therefore, the conclusion is that innovation can be created without R\&D. The lowtech industry is capable of doing so. Innovation can no longer be defined as radical changes but improving what already existed can also be called innovation. Moreover, creating innovation is an open process, meaning that the cooperation and collaboration between various actors are required. This collaboration and cooperation among actors in a region can be directed through policy. The policy for arranging actors in order to create a conducive climate for innovation is called the Concept of Regional Innovation System.

\section{METHODOLOGY}

This study uses qualitative case study research to answer the main question: How does low-tech innovation make a contribution to local economic development. The analysis concerns batik innovation, which is created by collaboration among actors and the impact of this innovation on economic development.

The snowball sampling interview technique is used to explore information from the interviewees much deeper. The interviewees consist of many different actors, such as industries, universities, vocational schools, governmental institutions, and other parties that have a correlation with the batik industry. The interviews were divided into two steps. The first step was the initial interview that was used as a basic reference in selecting the representative respondents who were in accordance with the study objective. The second step consisted of the in-depth interviews that were conducted with the selected respondents. The selected respondents consisted of four main respondents from the industry, three from universities and vocational schools, four from governmental institutions, one from a financial institution and one from a social organization.

\section{Overview of the Economic Condition in Pekalongan Municipality}

Pekalongan Municipality is a region in Central Java and is located in the northern part of Java. It is divided into 4 districts and 27 sub-districts. The population of Pekalongan in 2014 was 293.704 people with a population growth rate of about $0.01 \%$ (National Bureau of Statistics, 2015).

The processing industry is the second largest contributor to the GDP after the trade sector, contributing 21.67\% of Pekalongan's GDP in 2014 (National Bureau of Statistics, 2015). Even though the largest GDP contribution comes from the trade sector, the processing industry is the sector that provided the most job opportunities, contributing $35 \%$ of the total workforce in 2014 . One of the most developed processing industries is the batik industry. Batik has also become a superior product according to the Mayor's Decree No. 530/216 Year 2002 Concerning Superior Products.

The batik industry is a culture and is inseparable from Pekalongan's daily life. The history records show that Pekalongan Batik has existed since the 1800s. The industry has experienced ups and downs in its production. Its competitors come from other countries, such as China that produce textile with batik motifs. However, this did not discourage the batik industry in Pekalongan from producing batik. Three factors explain why the batik industry in Pekalongan still survives, i.e., (1) conducive policies and support from the 
government for developing the batik industry (Astuty, 2014; Bakhtiar et al., 2009; Christiana et al., 2014; Susanty, Handayani, \& Jati, 2013); (2) the power of its culture (Bakhtiar et al., 2009; Christiana et al., 2014); and (3) product innovations (Bakhtiar et al., 2009; Christiana et al., 2014).

\section{Innovation and Batik Industry}

Batik innovation has been created through collaboration among actors. The actors' role is influenced by the Pekalongan governmental policies, which have adopted the innovation system concept. The government of Pekalongan Municipality realized the importance of innovation in increasing the competitiveness of the region. Therefore, the Pekalongan government wanted to apply innovation system policy to develop an innovation climate for all of its work units to achieve the vision and mission of the region.

The application of innovation policy is adjusted to the visions of Pekalongan Municipality. One of Pekalongan's visions is to develop the city as a service city, prioritizing batik because it has the highest potency of the region. Several policies to support the creation of innovation in the batik industry include (1) creating links between researchers and users through a form of research, technology and innovation (Ristekin) which facilitates and provides research funds to connect university inventions to the users; (2) encouraging batik learning programs for the community by optimizing the functions of the batik museum, making batik a mandatory elementary school curriculum and encouraging the establishing of a batik faculty at the universities in Pekalongan.

Such collaboration can create four types of innovations, i.e., product innovations (natural coloring batik, new motifs); process innovations (using new natural materials e.g. indigo, tea leaves, and tree skin); organization innovations (new partner from training); and marketing innovations (e-marketplace). The process of innovation affects the result of product innovation during its creation.

The product and process innovations are the results of collaboration between the industry, universities, social organizations, and financial institutions. The entrepreneurs, as the representatives of the industry, conduct 'trial-and-error' based experiments to obtain the desired colors and patterns. They share their experiences while conducting the experiment, both the failures and the successes, with the other members of the informal organization ATIKA (Asosiasi Batik Warna Alam/Association of Natural Color Batik). The sharing of experiences is useful to receive positive inputs on the experiment from the other members. They also collaborate with the universities in the form of exchanging instructors, which can also help improve batik knowledge. Occasionally, they need funding for the experiments, so several entrepreneurs take up loans at Kospinjasa (one of the financial institutions in Pekalongan)

The organizational innovation is conducted by finding new partners for each training that is organized. The organizational innovation involves several actors such as the industry, the universities and the government (Department of Industry, Trade, and SmallMedium Enterprises and the Batik museum). Senior entrepreneurs conduct the training with the objective of transferring batik knowledge to new prospective entrepreneurs. The collaboration with universities (Pusmanu and Pekalongan University) is conducted by sending university students for an internship program in the entrepreneur's workshop. Realizing their contribution in preparing skillful employees and, in turn, benefiting local economic development, the government provides facilities for transferring their knowledge as a trainer in the batik museum. The Pekalongan batik museum functions as a workshop for both batik entrepreneurs and the community. Often, the participants of training sessions in the museum will continue their learning with the trainer of the workshop. The 
process benefits the entrepreneur because they can select the best prospective employees to be promoted as future business partners for the development of their business.

The collaboration between the industry, the government (Ristekin, Department of Industry, Trade and Small-Medium Enterprises) and a university (STIMIK) also results in marketing innovations. In this case, the government played an important role in linking the researcher/inventor to the user. STIMIK conducted a study on a one-market place and they received research funds from Ristekin. Ristekin then brought the research to the users. The Department of Industry, Trade, and Small-Medium Enterprises would then socialize the e-marketplace to the industry to facilitate the marketing of their products.

It can be concluded that five actors play an important role in the collaboration for generating batik innovation in Pekalongan Municipality. They are the industry, the government, universities, social organizations and financial institutions. However, not all five actors are involved in the creation of every kind of innovation; some innovations are based on the involvement of only a few actors. The government policies provide direction for the role of the actors in generating innovations.

\section{THE RELATIONSHIP BETWEEN LOW-TECH INDUSTRY INNOVATION AND LOCAL ECONOMIC DEVELOPMENT}

Innovation in batik industry has had a positive impact on local economic development such as savings raw materials; industrial spillover leading to the emergence of new entrepreneurs; creating job openings; and multiplier effects in the economic sector. Table 1 shows that product and process innovation has provided benefits and added value to the entrepreneurs and for environmental sustainability. Saving raw materials such as water and dye and using recycled cardboard for 'canting' (a pen-like tool used to apply liquid wax on batik) is an important issue in product and process innovations. An entrepreneur claimed that he could save water usage for the dyeing process up to $90 \%$ by using an invention called a viksator for lightening the color. Meanwhile, for material coloring, batik entrepreneurs choose to use natural materials that could be found locally such as tea and indigo leaves.

The most visible impact of organizational innovation is the growing number of entrepreneurs. Senior entrepreneurs regularly open workshop classes for learning batik. Generally, the workshop participants are those who want to develop batik businesses themselves. The workshop class' objective is not only to transfer batik knowledge but also to look for work partners. Such partners would be a business development asset. After the workshop is finished, the participants form informal organizations to share ideas and experiences among its members. Sometimes, they conduct research to create an invention in both the process of creation and marketing, especially for natural color. An entrepreneur confessed that in the last three years he had accepted and graduating almost 51 new entrepreneurs who studied the process of creating natural color and how to sell it. If this statement is compared with data from the Department of Industry, Trade, and SmallMedium Enterprises (Disperindagkop UMKM) on the number of batik business in Pekalongan Municipality, it explains how the number of businesses could grow about $6.4 \%$ annually for the last 5 years. This growth also had a positive impact on the number of workers, which also increased about 3.8\% annually in the last 5 years.

Marketing innovation has provided benefits in the form of reduced transportation costs and a place to market products using e-marketplace systems. Transferring batik knowledge through a practice of showing consumers the production process has attracted them to buy and learn to make batik. While they buy batik, the customers can register for batik training offered by entrepreneurs. This practice leads to new entrepreneurs. 
Table 1 The Economic Impact of Batik Innovation

\begin{tabular}{|c|c|c|c|}
\hline \multirow{2}{*}{$\begin{array}{l}\text { Innovation } \\
\text { Type }\end{array}$} & \multicolumn{3}{|c|}{ The economic impact } \\
\hline & Before & After & Benefit/added value \\
\hline $\begin{array}{l}\text { Product and process } \\
\text { innovation }\end{array}$ & $\begin{array}{l}\text { - An entrepreneur needs } \\
3000 \text { ml of water and } \\
90 \text { gr. Of synthetic } \\
\text { color for one-time cloth } \\
\text { dyeing. } \\
\text { - Using copper canting } \\
\text { that cost about } \\
250.000-600.000 \\
\text { rupiahs }\end{array}$ & $\begin{array}{l}\text { - An entrepreneur } \\
\text { discovers a *viksator. } \\
\text { Entrepreneurs use it } \\
\text { with natural coloring } \\
\text { material such as tea } \\
\text { and indigo leaves. The } \\
\text { viksator can reduce } \\
\text { water usage for cloth } \\
\text { dyeing. It only needs } \\
250 \text { ml of water for } \\
\text { one-time cloth dyeing. } \\
\text { - Entrepreneurs also try } \\
\text { to make their own } \\
\text { canting made from } \\
\text { recycled cardboard }\end{array}$ & $\begin{array}{l}\text { - More environmentally } \\
\text { friendly } \\
\text { - Reducing production } \\
\text { cost }\end{array}$ \\
\hline Organization innovation & $\begin{array}{l}\text { Entrepreneurs compete } \\
\text { with other entrepreneurs } \\
\text { to get skillful worker by } \\
\text { offering a higher salary. } \\
\text { This condition leads to } \\
\text { unfair competition } \\
\text { among entrepreneurs. }\end{array}$ & $\begin{array}{l}\text { Entrepreneurs } \\
\text { organize workshops to } \\
\text { look for work partners } \\
\text { instead of just a } \\
\text { knowledge transfer. }\end{array}$ & $\begin{array}{lr}\text { - } \begin{array}{lr}\text { Creating skillful } \\
\text { workers }\end{array} \\
\text { - Encouraging the } \\
\text { growth of new } \\
\text { entrepreneurs }\end{array}$ \\
\hline Marketing innovation & $\begin{array}{l}\text { Conventional sales with } \\
\text { open or } \\
\text { showrooms }\end{array}$ & $\begin{array}{l}\text { - Using the e- } \\
\text { marketplace system. } \\
\text { - Entrepreneurs also } \\
\text { show the batik making } \\
\text { practice process to } \\
\text { consumers instead of } \\
\text { just selling the } \\
\text { product. }\end{array}$ & $\begin{array}{l}\text { - Reducing } \\
\text { transportation costs } \\
\text { - The practice can lead } \\
\text { to consumers learn } \\
\text { batik production and } \\
\text { finally leads to new } \\
\text { entrepreneurs }\end{array}$ \\
\hline
\end{tabular}

*viksator is the material to lighten the color

Source: Analysis, 2016

Besides the various economic benefits mentioned above, the batik business has also affected the growth of other economic sectors such as trade and services. According to Astuty (2014), the increase in the number of hotels and restaurant is triggered by the batik business. Data from the National Bureau of Statistics (2015) disclosed that of the number of hotels increased from 23 in 2010 to 28 in 2014. The same thing happened for the number restaurants, which increased from 291 in 2010 to 308 in 2014.

In addition, the batik industry had a positive effect on the tourism sector through the learning batik program. In this program, the government supports the batik industry by optimizing the museum's function. The support comes not only from the local government but also from the central government in the form of the inauguration of Pekalongan Batik Museum as a means of promotion on the global level through providing information and teaching batik (Ministry of Trade of the Republic of Indonesia, 2008). The workshop classes at the batik museum have been able to attract tourists both domestically and from abroad (National Bureau of Statistics, 2015). In 2014, 18.071 tourists visited the museum. This figure increases in comparison with the previous years. From 2011 until 2013, the number of tourists was 12 308, 14 640, and 17823 (National Bureau of Statistics, 2015). 


\section{CONCLUSION}

The paradigm that views the high-tech industry as the industry with the most potential to generate innovation and boost the development of the local economy needs to be changed. This study shows that a low-tech industry has been able to innovate through collaboration among actors. The batik industry in Pekalongan Municipality has produced four types of innovations, i.e., product innovation with new motifs and natural color; innovation processes using natural coloring material; organizational innovation through opening workshop classes for new entrepreneurs; and marketing innovation which includes the invention and the use of an e-marketplace. Batik innovation was created through the collaboration of five actors, i.e., the industry, the government, universities, social organizations and financial institutions.

The Pekalongan batik industry has also generated direct and indirect positive impacts on the local economy. The direct impacts affect the batik business continuity and usually relate to entrepreneurs, e.g. revenue, an increase in the number of businesses and workers. A revenue increase occurred due to product and process innovation through raw material saving. An entrepreneur can save around $15 \%$ production costs and will get nearly $50 \%$ of sales profit. On the other hand, the batik business is growing because of organizational innovation, which is conducted by opening batik workshop for new entrepreneurs. The classes can attract the community to learn to produce batik and develop it into a business themselves. Such conditions can help accelerate the development of new entrepreneurs, aside from other conditions such as ease of business policy or mandatory batik uniforms for students and government employees on certain days.

The indirect impact of the batik industry is a multiplier effect that affects several sectors such as trade and services (Astuty, 2014). This study shows that the marketing and organization innovation has also increased the tourism sector. The influence on the trade and service sector can be seen from the rise in the number of restaurants $(1.1 \%)$ and hotels $(4 \%)$ annually for the last 5 years. The tourism sector's growth has been driven by the batik museum. It opens workshop classes for the community and has trained 18,071 participants both domestic and foreign alike in 2014 (National Bureau of Statistics, 2015). For the last 4 year, the museum visit rates have increased about $10.07 \%$ annually.

Therefore, this study proves that innovation is contributing to local economic development through increased income and the emergence of new entrepreneurs. On the other side, the new entrepreneurs have also created innovation. The relationship between innovation and entrepreneurs is that they mutually influence each other in developing the local economy. However, innovation is not only created by entrepreneurs. It may be true that some novelty ideas may come from entrepreneurs. However, the collaboration with other actors is required to further develop an idea into innovation to generate added economic value.

\section{ACKNOWLEDGEMENT}

The authors are very grateful for the fruitful inputs from Tommy Firman and Ridwan Sutriadi during the research process. However, the authors are solely responsible for the content of this article 


\section{REFERENCES}

Abernathy, W. J., \& Utterback, J. M. (1978). Patterns of industrial innovation. Technology Review, 80(7), 4047.

Acs, Z. (2006). How is entrepreneurship good for economic growth? Innovations, 1(1), 97-107.

Asheim, B. T., \& Isaksen, A. (2003). 2. SMEs and the regional dimension of innovation. Regional Innovation Policy for Small- Medium Enterprises, 21.

Asheim, B. T., Isaksen, A., Nauwelaers, C., \& Tödtling, F. (2003). Regional Innovation Policy for Small- Medium Enterprises. Edward Elgar Publishing.

Astuty, E. D. (2014). Conditions and the Existence of Cluster Development Business Batik Pekalongan City, Central Java, Indoensia. European Journal of Business and Management.

Audretsch, D., \& Keilbach, M. (2004). Entrepreneurship Capital and Economic Performance. Regional Studies, 38(8), 949-959.

Bakhtiar, A., Sriyanto, \& Amalia. (2009). Analisa Faktor-Faktor Yang Mempengaruhi Pengembangan Kreativitas Industri Kerajinan Batik. J@ TI UNDIP, 4(1), 27-41.

Blechinger, D., Kleinknecht, A., Licht, G., \& Pfeiffer, F. (1998). The impact of innovation on employment in Europe: an analysis using CIS data. ZEW-Dokumentation.

Castells, M., \& Hall, P. (1994). Technopoles of the world: The making of 21st century industrial complexes. New York: Routledge.

Christiana, Y., Pradhanawati, A., \& Hidayat, W. (2014). Pengaruh Kompetensi, Pembinaan Usaha dan Inovasi Produk terhadap perkembangan Usaha (Studi pada Usaha Kecil dan Menengah batik di Sentra Pesindon Kota Pekalongan). Diponegoro Journal of Social and Politic, 1-10.

Cooke, P., \& Memedovic, O. (2006). Regional innovation systems as public goods. UNIDO.

Crumpton, M. A. (2012). Innovation and entrepreneurship. The Bottom Line, 25(3), 98-101.

Department of Industry, Trade, and small-medium enterprises. (2015). Laporan data UKM Batik. Pekalongan: Department of Industry, Trade, and small-medium enterprises.

Edquist, C., Hommen, L., \& McKelvey, M. D. (2001). Innovation and employment: Process versus product innovation. Edward Elgar Publishing.

Fagerberg, J. (2003). Innovation: A Guide to the Literature, The Many Guises of Innovation: What we have learnt and where we are heading. Statistic Canada: Ottawa.

Fahmi, F. Z., Koster, S., \& van Dijk, J. (2016). The location of creative industries in a developing country: The case of Indonesia. Cities, 59, 66-79.

Godin, B. (2008). The Moral economy of technology Indicators. In Innovation in Low-Tech Firms and Industries. Northampton: Edward Elgar Publishing Inc.

Hatzichronoglou, T. (1997). Revision of the high-technology sector and product classification.

Hirsch-Kreinsen, H. (2008). “ Low-technology”: a forgotten sector in innovation policy. Journal of Technology Management \& Innovation, 3(3), 11-20.

Hirsch-Kreinsen, H., Jacobson, D., Laestadius, S., \& Smith, K. H. (2005). Low and medium technology industries in the knowledge economy: the analytical issues. Retrieved from http://eprints.utas.edu.au/1299/

Kaufmann, A., \& Tödtling, F. (2003). Innovation Patterns of SMEs. In Regional Innovation Policy for SmallMedium Enterprises (pp. 78-118). Northampton: Edward Elgar Publishing Inc.

Kementerian Perindustrian Republik Indonesia. (2013). Kemenperin: Tahun Ini, Ekspor Kerajinan Bisa Tembus US\$ 770 Juta. Retrieved September 23, 2017, from http://kemenperin.go.id/artikel/6165/

kementerian Perindustrian RI. (2016). Kemenperin Optimis Eskpor kerajinan tumbuh 5\%-10\% pert tahun. Google Search. Retrieved March 26, 2017, from https://www.google.com/search?q=Kemenperin+Optimis+Eskpor+kerajinan+tumbuh+5\%25$10 \% 25+$ pert+tahun. $+\&$ ie $=$ utf-8\&oe $=$ utf- $8 \&$ client $=$ firefox-b

Lawton-Smith, H. (2009). The high-tech cluster of Oxfordshire, United Kingdom (pp. 73-100). Organisation For Economic Co-operation and Development (OECD).

Lembaga Pengembangan Perbankan Indonesia, \& Bank Indonesia. (2015). Profil Bisnis Usaha Mikro, Kecil dan Menengah (UMKM) - Google Search. Retrieved from https://www.google.com/search?q=Kemenperin+Optimis+Eskpor+kerajinan+tumbuh+5\%25$10 \% 25+$ pert+tahun. + \&ie $=$ utf-8\&oe $=$ utf-8\&client $=$ firefox$\mathrm{b} \# \mathrm{q}=$ Profil+Bisnis+Usaha+Mikro,+Kecil+dan+Menengah+(UMKM) \&*

Lundvall, B.- \AAke, Johnson, B., Andersen, E. S., \& Dalum, B. (2002). National systems of production, innovation and competence building. Research Policy, 31(2), 213-231.

Ministry of Trade of the Republik of Indonesia. (2008). Indonesia Batik: A Cultural Beauty. Jakarta: Trade Research and Development Agencies.

Muharti, A. (2012). Nilai Ekspor Industri Kreatif Makin Meningkat - Kemendag Targetkan Transaksi Inacraft Naik 15\%. Retrieved September 23, 2017, from http://www.neraca.co.id/article/13011/kemendagtargetkan-transaksi-inacraft-naik-15-nilai-ekspor-industri-kreatif-makin-meningkat 
Mutlu, B., \& Er, A. (2003). Design innovation: Historical and theoretical perspectives on product innovation by design.

National Bureau of Statictics. (2015). Pekalongan Dalam Angka 2015. Pekalongan: National Bureau of Statistics.

National Research Council, \& others. (2013). Best practices in state and regional innovation initiatives: competing in the 21st century. National Academies Press.

Nelson, R. R. (2008). Economic development from the perspective of evolutionary economic theory. Oxford Development Studies, 36(1), 9-21.

Park, S. O. (2001). Regional innovation strategies in the knowledge-based economy. GeoJournal, 53(1), 29-38.

Pike, A., Rodríguez-Pose, A., \& Tomaney, J. (2006). Local and Regional Development. New York: Routledge.

Potter, J. (2009). The Micro-nanotechnology cluster of Grenoble, France. In Cluster, Innovation and Entreprenuership (pp. 43-72). Organisation For Economic Co-operation and Development (OECD).

Quintas, P., Wield, D., \& Massey, D. (1992). Academic-industry links and innovation: questioning the science park model. Technovation, 12(3), 161-175.

Rocha, H. O. (2004). Entrepreneurship and development: The role of clusters. Small Business Economics, 23(5), $363-400$.

Rutten, R. (2005). Knowledge and innovation in regional industry: an entrepreneurial coalition. Routledge.

Schumpeter, J. (1983). The theory of economic development An inquiry into profits, capital, credit, interest and the business cycle. New Brunswick (U.S.A): Transaction Publishers.

Susanty, A., Handayani, N. U., \& Jati, P. A. (2013). Analisis Faktor-Faktor Yang Mempengaruhi Pertumbuhan Klaster Batik Pekalongan (Studi Kasus Pada Klaster Batik Kauman, Pesindon Dan Jenggot). J@ TI UNDIP: Jurnal Teknik Industri, 8(1), 1-14.

Tan, J. (2006). Growth of industry clusters and innovation: Lessons from Beijing Zhongguancun Science Park. Journal of Business Venturing, 21(6), 827-850.

Zhao, F. (2005). Exploring the synergy between entrepreneurship and innovation. International Journal of Entrepreneurial Behavior \& Research, 11(1), 25-41. 